\title{
Titian, tapestries and toilets; what do preschoolers and their families value in a museum visit?
}

\author{
Nicola Wallis
}

\begin{abstract}
What do preschool children value about museums, and how can we find out? This case study focused on children of preschool age (three and four years) who were already experienced visitors to our UK art museum. They were given a cuddly toy to take on a guided tour of the museum in order for them to highlight what they considered key objects and features. This enabled many rich and indepth conversations between the children, their parents and the researcher. The children were also invited to draw - about their museum visits - and parents were interviewed to give their perspectives on their children's museum experiences. Analysis of the children's talk revealed that they valued many different aspects of the experience of visiting the museum - not just the activities and resources specifically designed for families - and displayed a good deal of 'museum literacy' in addition to carrying out sophisticated analyses of particular objects. The study calls for greater focus on this age group in museum education, particularly through research led by practitioners, who observe on a daily basis how young children express their relationships with museum objects, and who have a wealth of local experiences which could be developed through thoughtfully planned action research.
\end{abstract}

Key words: museum education, early education, early childhood, practitioner-led research, visual arts, voice of the child

\section{Introduction}

This project was developed in response to a rapidly increasing demand from families visiting the Fitzwilliam Museum for programming specifically designed for preschoolers. Many museums around the country and further afield are finding ways to respond to this demand, and there are a wide variety of approaches being offered to families. I wanted to find out what families consider is valuable about such experiences in order to develop my own practice in ways that would be supportive and relevant to young children and their families. This small, practitionerled study aimed to open a dialogue in which children and their parents could contribute their opinions and experiences with a view to influencing the direction of future educational programming for young children.

I work at the Fitzwilliam Museum in Cambridge, UK. It is in many ways a very traditional university art museum which is not immediately accessible to young children: none of the objects may be touched, paintings are hung at adult height, often with antique furniture in front, and many of the objects in the antiquities and applied arts galleries are housed in glass cases. Labelling follows accepted conventions: explaining maker, place, date and material and usually nothing further. Information panels are used infrequently, and have an academic tone and level of detail. There are Titians, there are tapestries but generally no interactive or 'hands-on' exhibits, no specially designated areas for children in the galleries, and nothing to play with.

However, a high proportion of visitors to the museum are young children and their families. I facilitate a regular session for two and a half to five year olds, and it is always oversubscribed. What is it that motivates them to visit the museum, and to keep coming 
back? Other museums around the UK and internationally have also developed exciting and innovative programming for this age group which is extremely popular with families. Examples include Manchester Museum at Manchester University, which as part of their 2014 redevelopment created the Nature Discovery Gallery, specifically aimed at under-fives, as well as the Whitworth Art Gallery, The Herbert Art Gallery, The Museum of London and Ipswich Art Gallery, Queensland, Australia. There is something about the museum which interests some families with pre-school aged children. I intended to find out from the families, and from the children in particular, where this appeal might lie.

\section{The research process: Practitioner-led research}

Some may question the validity of a project like this one in which the researcher has previously worked with the participants as an educator. How can judgements be impartial? Will the children automatically recall and discuss previous facilitated sessions in order to please the practitioner/researcher? Will participants feel obliged to be complimentary about the museum and its services to a member of its staff? These questions were also of concern to me, and I took measures to counteract these possibilities, explaining to the children that the cuddly toys that they were invited to show around the museum and I were interested in seeing new as well as familiar things in the museum (indicating that I did not only value objects we had seen together in facilitated sessions), and reassuring parents that honest answers and comments about the museum would not have negative effects, either on themselves or on staff at the museum, who are in any case already used to working on frequent feedback and evaluation information from visitors.

Even bearing these concerns in mind, I am now convinced of the need for practitionerled research within the context of early learning in museums, and I hope that in addition to its insights into what children value in museums, this project also goes someway to demonstrating the usefulness of museum educators carrying out their own research. Pascal and Bertram (2012) highlight how the inherently reflexive, participatory and action-focused nature of practitioner research moves towards a model of steering and driving change through innovative practice. This implies a fast transfer of knowledge from research straight back into practice which means almost immediate impact on visitors of new knowledge gained from research. Additionally, practitioner-researchers are well placed to influence or support colleagues who engage in similar work:

Their [practitioner researchers'] particular values lie in their positionality, close to the site of professional action...The knowledge they generate for application in their own work is also transferable to other practice situations... if well documented and disseminated (Pascal and Betram, 2010).

\section{Theoretical Framework}

When working directly with young audiences to find out what they value in museum services, evaluators have tended to focus on teenagers and school-aged children (Xanthoudaki et al, 2003; Gross et al. 2003). However, I was interested in developing a methodology based on the kind of relational pedagogy (Papatheodorou and Moyles, 2009) I employ in my everyday practice, which would enable younger children to think about and communicate their views on these issues. This approach respects the socio-cultural experiences that children bring to the museum, and respects all their contributions: positive and negative, verbal and non-verbal, as important and valid.

This involved devising research tools which are accessible to young children and their developing communication skills, and which would be of interest to them. Dowling (2013) acknowledges that even very young children are active and capable thinkers. The challenge for educators is how to create opportunities to 'move closer to the child's thinking' (Dowling, 2013, 108).

I aimed to draw on a variety of methods to help children to articulate what it is that they value in this particular museum. Kirk (2011) describes the potential for adapting the Mosaic approach (Clark and Moss, 2001) to a museum context. Its varied and participatory nature 
is perhaps closer to children's usual experiences of family programming in museums than traditional ways of collecting the views of adult visitors such as questionnaires or tracking. It also supports the gathering of data in a way that is sympathetic to current theories of museum learning (eg Hein, 1998), taking into account social constructivist aspects of learning (that is to say, learning that is socially situated and created through interaction with others) rather than simply testing a gain in knowledge.

To represent the children's experiences accurately, I triangulated their responses with those of their accompanying adults, and took steps to support children's multi-layered discourse: not just speech, but also gestures, utterances and physical movement. Observing or interviewing alone is unlikely to reflect the true depth of children's thinking - they must have the opportunity to engage with the researcher in genuinely dialogic ways:

Listening to children implies engaging with them in sustained dialogues, as well as observing and participating with them in different activities (Assunçao Folque, 2010: 256).

By considering how to hear the voice of the child in this project, I hoped not only to develop a better understanding of their views of the museum but also to highlight the research potential of the close relationships that develop between practitioners and children.

This work was an interpretive case study. The study was limited to a small number of children for reasons of time and resources. However, the small scale of the project also meant that the analysis and ensuing recommendations could be quickly reworked back into my regular practice. The small number of participants necessitated a focus on how to elicit and describe children's views as accurately as possible, yielding authentic rather than generalizable results.

Working within a social constructivist paradigm - in which knowledge is defined as personal meaning-making - necessitated taking a multi-dimensional, dialogic approach which attempted to capture a detailed picture of the children's experience in the museum, taking into account that socio-cultural, cognitive, aesthetic, motivational and collaborative experiences will all have an impact in how the children encounter and describe the museum (Anderson et al., 2002).

Building on the view that human development and knowledge is socially-constructed through interaction with others is the importance of children's rights theory: that children have the right to be heard and to be active participants in these interactions (Smith, 2011). In this project, as both a practitioner and researcher, I felt it was my duty to encourage and enable children to both form and contribute their own views which I did by asking them to show a cuddly toy around some of the best places in the museum - perhaps something they had enjoyed on a previous visit with their families, or noticed during a facilitated session. This situated the children as autonomous experts, with the power to make their own choices about the 'best' places: there was no set route, and having the children in role as tour guides mean that adults stood to one side, allowing children to make the decision about where to go.

Kirk (2013) highlights the importance of communicating directly with children about their museum visits, as accompanying adults will have had varying degrees of input and influence on how the children have encountered the museum objects, and so can only give a partial description of their children's experiences. Having a cuddly toy made the children's choices more visible to the researcher, without the need for intercession from parents. Additionally, using a toy as a mediator of the children's thoughts meant that they could employ a number of communication methods and were not solely reliant on verbal interactions; the children danced the cuddly toys excitedly at some moments, or pushed them up close to the glass as if to study certain objects in more detail for example. This indirect way of finding out children's views using props and games rather than conventional interviews is more appropriate and likely to be successful with young children (Graue and Walsh, 1998). 


\section{Recruitment}

I selected a group of families to receive invitations to participate in the project based on the following criteria:

- The children were aged between 36 and 52 months

- They had taken part in facilitated sessions at the museum more than once in the last six months

- They had given consent for the museum to store their addresses and contact them via email

Three families took part in the museum visit and follow-up session: Emma (aged four), Orla (aged four) and Lily (aged three), who were accompanied by their mothers (names have been changed for reasons of confidentiality). The group remained together throughout the visit to the museum.

\section{Museum Visit}

The children were given the task of introducing a soft toy to the museum collection. Before going into the galleries, we discussed potential things to show to the toys, touching on previous experiences and memories and drawing out the idea of what the children hold as valuable and important parts of the museum experience to pass on. This enabled me to ensure that each child was able to have some input into which galleries to visit, and which objects to see. We spent time walking through the galleries, pausing at points of interest for the children and discussing what they valued or remembered about the objects. Similar approaches using semi-structured museum tours led by the children are recommended by Potter (2006) and Weier (2004). A colleague video-recorded this experience, while I took brief notes. Having two 'observers' working together also made it possible to be in two places at once when the group separated to look at different things (Rolfe and Emmett, 2010). Taylor (2010) recommends a combination of observational techniques to minimise bias, error and omission, and thus increase reliability.

Following the usual pattern of visits, we moved from the galleries into the education studio towards the end of the visit where the children were given access to drawing materials. The aim was to create a relaxed atmosphere - children had a very broad brief as to what they could draw (something they enjoy at the museum) and were provided with a wide-range of drawing materials. Familiar education assistants were on hand to chat casually with the children, provide refreshments and draw alongside them.

Although children's drawings can be wonderfully insightful, I did not intend to make them a major part of my study. The opportunity to draw was primarily a 'holding' activity to allow the children to remain engaged and occupied while I spoke in detail to their parents.

During the drawing session, I conducted an informal focus group interview with the accompanying adults, which helped me to clarify, contextualize and validate comments and issues raised by the children, and to provide background information on their families' relationship with the museum. I was aware that there was also the potential for contradiction as parents and children may have had a different view of the same experience, however, the adults' discussion quickly turned to a focus on their own stories as parents bringing children to the museum so there were limited discussions of overlapping experiences with the children's cuddly toy tour.

\section{Data analysis}

\section{Children in the galleries}

I employed a grounded theory approach to examine the data. After a number of close viewings of the video recordings, I transcribed all usable data and undertook a content analysis. These repeated viewings gave me a sense of the data and initial themes and categories which seemed to be particularly prominent. I needed to be sure that these themes were coming from my 
data and not from my preconceptions, and with this in mind I focused on the data itself when generating categories by which it could be analyzed.

With such a small number of participants identifying clear patterns in their responses was rather difficult, so instead I focused on examining the data for salience to the research questions. As Graue and Walsh (1998) indicate, this is necessarily interpretative; a legitimate approach given the small scale and site-specific nature of the research.

Once I had established categories based on recurring themes and repeated types of exchanges that I observed, and used them to organize the data, I analyzed the categories once more, testing to see whether there were too many (i.e. sufficiently similar to be combined) or too few (i.e. subtle differences that would be better represented in separate categories). I also considered the relative importance of the different codes and whether any connections could be established, for example between preferences for similar types of objects or whether having encountered an object during a facilitated session made it more likely to be identified as something of value.

\begin{tabular}{|r|l|}
\hline 1 & Recognition of what an object is or represents eg 'It's a horse.' \\
\hline $2 a$ & Memory of a facilitated session - gallery work \\
\hline $2 b$ & Memory of a facilitated session - studio work \\
\hline 3 & Memory of another previous visit \\
\hline 4 & Simple description of properties - for example shape, colour, size, position \\
\hline 5 & Personal judgement - like or dislike \\
\hline 6 & Personal judgement - deduction/analysis/evaluation of an object \\
\hline 8 & Connecting an object to the real world (beyond naming it) \\
\hline 9 & Connection to another museum object \\
\hline 10 & Question - other regarding object \\
\hline 11 & Question - regarding another's perception \\
\hline 12 & Agreement \\
\hline 13 & Disagreement \\
\hline 14 & Acting as a guide by drawing attention \\
\hline 15 & Acting as a guide in another way \\
\hline 16 & Playing with the cuddly toys \\
\hline 17 & Referring to physical comfort or features of the physical museum environment \\
\hline
\end{tabular}

During the process of coding, I realized that categories 12 and 13 were too broad. I split these into $12 \mathrm{a}$ - agreement/reinforcing another's view/copying

$12 \mathrm{~b}$ - aligning/affiliating oneself with another

$13 a$ - disagreement, correcting another's statement

$13 \mathrm{~b}$ - dissociating oneself from another, separating from others,

in order to be able to analyze more accurately the moments of closeness and division among the group. I also added an additional category of $9 a$ - uncertainty, for moments when the participants seemed unsure what to do or say, but did not ask a question.

These categories helped me to understand the many different layers of the children's experiences of the museum, and to be able to articulate them distinctly. Of course, at this 
stage my input as the researcher becomes even more overt, and there is a risk that the participants' voices become subordinate to my own interpretations. However, Bryman (2008) is reassuring on this:

Your findings acquire significance in our intellectual community only when you have reflected on, interpreted, and theorized your data. You are not there as a mere mouthpiece (554).

My aim is that my interpretation below will make the meanings expressed by the children clear and relevant to others, and that my reading of their words will not only be analytical but also constructive, enabling future dialogue between the children's ideas and the development of provision for them.

\section{Research Findings - ways in which children value the museum \\ Valuing the museum as a place for social interaction}

Perhaps most striking is that the most common type of comment made by the children was not directly concerning the objects, but rather expressing agreement with others in the group. This seems to situate this kind of museum visit firmly in the realm of a shared, social experience, which is why a socio-constructivist approach is helpful in analyzing this encounter with the museum. The children are interested in comparing how their own ideas enable them to make connections with their peers and how these allow them to construct their social identity within the group.

Here is an example of the three children looking at a ceramic owl together:

Lily: I saw a owl!

Emma: Me too.

Lily: I saw a owl. Sometimes I go to preschool, and I see owls at preschool.

Emma: Really?

Lily: Yeah.

Emma: Real or pretend?

Lily: Yeah. Really. Real.

Orla: I haven't seen a real owl in real life.

Lily: Hey! I saw three owls. A little one, and a size one, and a big one.

Leinhart and Crowley (1998) cite a variety of previous studies which confirm the importance of visitors' identities as defined by their prior experiences and particular interests and individual motivations on how they experience the museum, and so perhaps it is not surprising that young children are also interested in how their individual experiences compare with those of others by expressing shared ideas and interests.

\section{Valuing the museum as a place for wondering}

Another key finding when coding the data, of which I was not aware when making my field observations, was how few questions the children asked. They only asked a total of five questions during their whole time in the museum galleries (approximately one hour).

Could this lack of direct questions be another function of the role I had asked the children to take as tour guides? Perhaps the children saw themselves more as answerers than questioners on this occasion. However, although the children relished the opportunity to shape the visit, using the toys to take control over where to go in the museum: 'My Teddy says he wants to go upstairs!', the role of tour guide was not particularly reflected in their use of language, which was generally much more focused on the first person. At times, the cuddly 
toys were used as mouthpieces to voice the opinions of the children, particularly when these were controversial or in opposition. Here is a discussion in the Far Eastern Gallery:

Lily: [indicating a small porcelain bottle painted with a dragon by waving her cuddly toy towards it] Here! Here! There's one dragon here. He likes the little dragon.

Emma: [turning her cuddly elephant towards her, as if listening to it] He thinks it's a pot.

Me: Well, I think they're both right, aren't they, because it is a pot and it's got a little dragon on it.

Orla: [holding up her cuddly meerkat] This one likes this one [indicating the small bottle] and this one [holding up her cuddly puppy] likes the big one [indicating a large jar, also painted with a dragon].

However, the children quickly forgot all about the toys and their role as tour guides when they identified objects of interest, indicating that it was the act of looking rather than the act of showing which was motivating their choices in the galleries. Once they became interested in looking at and discussing objects, they seemed to want to experience this for themselves, rather than try imagine what it was like for the toy and act this out for the benefit of those listening. Similarly, in this next vignette, Orla's speech seems only loosely intended as a way of communicating with others. Although she is aware of what others are saying, and it seems to impact on her train of thought, her focus seems fixed on the object, and she kept her gaze directly on it, not looking at any of her interlocutors throughout. In the ceramics gallery, Orla made straight for an early nineteenth century earthenware figure of Lieutenant Hugh Munro being mauled by a Bengal tiger.

Orla: The tiger's got

Me: Oh no!

Orla: I don't know what it's got.

Lily: [pointing at a different figure] Look! A leopard.

Orla: Eyes are closed. That means he's dead.

Me: Do you think?

Orla: By his teeth.

Me: Oh my goodness!

Lily: (pointing at the same figure as earlier) Look! A leopard! A leopard!

Me: [to Orla] How scary! [to Lily] And a leopard. He looks much friendlier, that leopard, I think.

Orla: Yeah. But we can't go near tigers, leopards or lions because we will get killed because they're not nice ones.

Me: No, these are not pets, are they?

Orla: [turning away from the cabinet to face me] Pardon?

Me: They're not pets, these animals.

Orla: [looking back into the cabinet at the tiger] No. They're wild. 
In this case again Orla began by analyzing what she could see, and then matching this to prior knowledge and understanding. Rather than asking questions directly, to another person, she is using her curiosity as a springboard to challenge herself to think more deeply about what she is seeing. She is neither a questioner, nor an answer-giver. She is a wonderer.

\section{Valuing the museum as a place for raising expectations and inspiring ideas}

Contrast this potential for high order thinking and deduction that Orla demonstrates relatively independently with a conversation she had with her mother in the Armoury. Her speech is much sparser and there is little evidence of how her thoughts develop in response to the objects.

Orla's mum: What's that? That's a sword, isn't it? Do you like that one?

Orla: Yeah.

Orla's mum: What's your favourite?

Orla: That one.

Orla's mum: That one? What colours are on it?

Orla: There's blue and red, and green and orange.

Orla's mum: Yeah?

Orla: And the birdy.

Orla's mum: And the birdy? What else do you want to look at?

Orla: He's white.

Orla's mum: You're right. Where shall we go next?

Here, Orla seems relatively unengaged with the objects. Her mother leads her choice of what to look at, and then the features on which to focus. Orla gives the required answers but nothing more, and her mother seems anxious to move onto the next thing rather than focus intently on a single object or idea. This gallery was the first of the visit, and so it may be the case that both Orla and her mother were simply acclimatizing themselves to the museum environment. However, it may also be indicative of the low expectations that parents (which we discussed later in our focus group), early years practitioners and even museum educators maintain, in respect of very young children's ability to function as independent museum visitors, making their own value judgements and deductions (Graham, 2008).

Another possible interpretation could be that Orla's mother's focus on only the very basic details about the objects might reflect her own anxiety about how to discuss with her daughter objects which are outside her own realm of knowledge. When I spoke to the parents together in the focus group, Lily's mother raised this as an issue and explained that she valued facilitated sessions as a way of introducing young children to the museum's collection. Although her family had visited local museums of geology and zoology independently, she suggested that she would not have felt confident to engage young children with fine art, and perhaps would have assumed that it would not be of interest to them until they were older, had the facilitated sessions not been available.

Similarly, Emma's mother, who described herself as frequent visitor to the museum with her children both as a participant in facilitated sessions and independently, spoke about how the facilitated sessions had extended her awareness of the potential of the art collection for young children. In particular, she identified a recent exhibition of contemporary Chinese porcelain (China's White Gold: Contemporary Porcelain from Jingdezhen - Fitzwilliam Museum: 18 December 2012-1 April 2013). She stated that, when visiting as a family, they would usually return to familiar favorites: the armor, portraits, fans and so on. She explained that she would not have thought of taking preschool aged children to see this exhibition, as it was not something 
that she knew anything about herself and so had presumed that it would be too esoteric or difficult for them to understand. However, the facilitated session held in this gallery had a huge impact on her, and she now tells friends that they must come and see Prosperity (white) by Caroline Cheng (more than 10,000 handmade porcelain butterflies stitched by hand onto fabric in the shape of a woman's dress or $f u$ ) which has since become one of her favourite objects: 'but without [the facilitated preschool session] I personally would never have seen it.'

Emma's mother's experience showed that adults, whether parents or museum educators, should not assume that just because something is outside their own range of expertise it would be impossible for them to introduce young children to it. In fact, all the parents agreed that discovering new things alongside their children was one of the most exciting aspects of museum visiting. They could have discovered these things on an independent visit too, but they valued the experience that a facilitated session afforded them.

Another key aspect of learning for the adults which came about through the facilitated sessions was, as Orla's mother described it, 'introducing the adults to how children can enjoy the museum.' All the parents had raised their expectations of their own children's capabilities and potential to understand the museum since taking part in the preschool programme:

I was surprised from how young you can bring them.... but [the preschool sessions] have shown me how children can react to the art. They think the museum is really exciting. That's brilliant, isn't it? (Orla's Mother)

We don't often give children credit for what they can do. Focusing on one or two objects in a session means they can concentrate for three quarters of an hour or more (Lily's Mother).

It is interesting that the parents were surprised at the level of engagement and enjoyment that their children could achieve in the museum. As described earlier on, the Fitzwilliam Museum is not what might be thought of as a typically child-friendly setting, but that did not stop the children in this study engaging with its collections and making personal connections. What we can learn from this is that it is not necessary to 'dumb down' the content of exhibitions or present artefacts in particular ways in order to make them of interest to very young visitors. They are able to engage with them on their own terms. Why is it so surprising that young children can connect in profound and sophisticated ways with what many of us agree is 'great art', that is, art that has something to say, that communicates well, that connects us with something?

Perhaps it is the kinds of spaces in which fine art is displayed, rather than the art itself, which makes it seem unlikely that younger children can make connections. Museums (and art museums in particular) have long been perceived as dry, dusty places; austere in their architecture and atmosphere, places controlled by those with expert knowledge who grant limited access to the uninitiated, and are most definitely the domain of adults seeking quiet contemplation (Black, 2005). Of course, museums in the UK are extremely diverse, and this kind of stereotype is neither accurate nor fair. However, it is true to say that generally, museum objects are displayed and curated based primarily on adults' needs and interests.

\section{Valuing the museum as a place with special atmosphere}

These children, who are regular visitors, did not seem to notice that the space they were in was not 'child-friendly' in terms of having things to touch, special displays at their height and so on. Perhaps the point that we have been missing here is that children's and adults' needs are not so very different. Hein (1998) suggests that we need not necessarily categorize our studies of visitors on the basis on their ages or stages of development, but staying true to the social constructivist view, we could instead consider visitors' previous experiences of the subjects on display. Having the interest, disposition, personal experience and motivation to enjoy a museum exhibition is not necessarily proportional to increasing age. What is important here is not necessarily the age of a person, but their prior experience and therefore the expectations they bring to the museum.

In contrast to what we might expect, these families did not want the museum to be a home-from-home environment, with all their usual creature comforts, but hoped for and enjoyed the special atmosphere of the museum. They described places they had visited with 'hands- 
on' activities and 'puzzles for the children' as 'handing it to parents on a plate'. Whereas as museum educators we might see these types of additions to exhibitions as helpful ways for families to engage with museum objects, and also as an implicit sign that family visitors are welcome, the parents I spoke to felt that there was a possibility that these kinds of facilities could actually have a negative impact on their visit. They felt that as parents visiting with their children, they had a 'joint responsibility' with the museum for educating their children about the objects and ideas on display, even when these were not objects familiar to them. What they valued much more highly than any version of 'family-friendliness' was simply the opportunity to have direct access to museum objects. It would be interesting to carry out comparative studies to assess how widespread this feeling is among families with varying experiences and expectations of museum visiting.

\section{Valuing museums as places that display objects and their stories}

It is the powerful impact of the museum objects themselves that remains with the children and their families. While good pushchair storage, easy-access toilet facilities and child-height displays and equipment would surely not detract from a visit, these are not sufficient to make a museum visit valuable to families. Anderson et al. (2002), in their much larger study of 99 children aged between four and six, found that 'children frequently recalled, and described in detail, museum experiences that were embedded in the medium of story,' (222) and also suggested that facilitated sessions were particularly memorable. I would suggest that this is perhaps owing to the fact that stories and teacher-class interactions are familiar experiences from outside the museum and hence children already have the mental frameworks on which to create memories of these types of experiences. As a practitioner I was excited when Emma began discussing a session she had taken part in over six months previously, with no prompting, and having not yet seen any of the objects used in the session. This was the story I tell at the museum of Juliette - a winkle gatherer on the French coast who encounters a magical horse and a friendly lion. At first I could not understand what she was describing as she had misremembered or changed the name of the main character in the story from Juliette to Wendy. However, when she filled in a few more details I was able to connect this with an experience we had shared much earlier in the year.

Emma: Where's the picture of the girl called Wendy?

Me: A picture of a girl called Wendy?

Emma: Yeah

Me: Um, now, which one? What does Wendy do?

Emma: She walks... with a shell. She gets shells and puts them in a basket. And she swims like this [gestures swimming arms].

Me: The one who's very good at swimming?

Emma: Yes

I realized that Emma was trying to ask me about Carpeaux's bronze sculpture La Pêcheuse de Vignots (The Winkle Gatherer) on which I had previously based a gallery story. When surrounded by the other objects that we had encountered on this visit, Emma was able to remember tiny details from before (for example a small crab at the winkle gatherer's feet, which was very difficult to see from the child's viewpoint), and retained a complex understanding of the story. Interestingly, Lily also began to remember elements of the story in the gallery, mentioning the horses and pirates that were involved in it:

Emma: Excuse me, but that's the horsey with the girl, called Wendy...The pirates stealed her, and made her pull their carriage, and one of her golden shoes got like- and fell into the sand, and the Wendy girl digged it out. She gave it back to the horse. 
Lily: Yeah, and there was a lion, and I made the horse. And I made the horse.

Emma: Yes, the lion, the lion, yes the lion. It's in here. See? And that's the pony and that's the lion. The unicorn and the lion are best friends. That's the horse and that's the lion. The lion, and the horse are best friends, ever.

\section{Valuing the museum as a place in which to start one's own collection}

De Botton and Armstrong (2013) argue that museums have made it difficult for individuals to make personal connections with the objects on display. They suggest it is difficult for museum visitors - embedded as they are in personal, family, work, sociological and political contexts - to appreciate how artworks may provide guidance, solace, inspiration and happiness when they are displayed in the decontextualized manner common to many contemporary museums and galleries. However, perhaps this is not simply a product of museum display alone, but how as adults we interpret this lack of interpretive guidance as an indication that there are truths and ideas about these artworks which we should somehow already know, narrowing down our potential to connect personally with the objects, and relate to them on our own terms. Young children, who have been assumed to know very little, are not similarly inhibited, and in this study, it was possible to see Orla taking a particular theme to her heart and using the museum as a springboard to start her own virtual collection of lions. Finding and commenting on the various lions in the museum was not stated explicitly as an aim by Orla, but it was clear that she was using the different lions she noticed in various parts of the museum to make a personal map for herself of places of key importance. De Botton and Armstrong discuss the importance of the museum gift shop as a place in which many visitors begin to make a personal connection with art, to see how it might fit into their lives. Orla, however, was able to create her own individual souvenir of the visit straight from the objects themselves. After leaving the museum galleries for the education studio, the children were invited to draw a 'museum picture'. Orla set about drawing straight away saying, 'meerkat [her cuddly toy to guide around the museum] liked the lions', quickly adding a 'zigzag for the mane'. In the following extract, she is very clear that lions are key to 'her' museum, and that it is permissible for individuals to have different preferences and understandings:

[Orla colours the lion in yellow.]

[Emma begins to draw a horse in yellow.]

[Adam (Museum Education Assistant) asks if they are both drawing yellow horses.]

Orla: I'm not doing a horse. I'm doing a lion - we're doing what they liked.

Emma: I can't do white [the painting she is thinking of shows a white horse]. I'm doing a golden horse.

Orla: I'm doing a golden lion - these spikes are gold.

Orla was very clear about which of the museum lions that she was drawing:

Orla: This is a nice lion...

Adam: Which lion are you drawing?

Orla: The nice lion with the lady.

Orla: I've done a really kind Mummy lion. It's got lipstick on - that's how I know it's a mummy lion.

Emma: It hasn't got any legs.

Orla: I'll do the legs after. 
Lisa [education assistant]: That's a lovely stripy lion.

Orla: It is a lion. It's a rainbow lion. I can do whatever I want in this picture. I'll do the sky after l've done the legs. I'm doing claws. You can't really see the claws or legs.

Although Orla's lion is her own creation, she based her drawing on the lion she saw in Stubbs' painting Isabella Salstonstall as Una in Spenser's 'Faerie Queene' (1782). This formed part of the story retold by Emma in the gallery, and clearly the incident described above in which Orla tried to make sense of the ceramic figure, or Munro, being mauled by a tiger also had an impact on her work; she knows there is another side to these big cats. She uses the process of drawing to integrate her understanding of what a lion or a tiger is: adding the claws to her picture, even though they were not shown in the Stubbs painting, is the way in which she references her earlier thoughts about the violent potential of such an animal.

\section{Conclusions}

The findings above show that the three children involved in the study encountered the museum in ways which were as sophisticated, multi-layered and personal as those that we might expect of adults. From their recorded interactions and responses to the museum, these children in particular valued the social, personal, intellectual, surprising, atmospheric and physical aspects of museums. Whilst the results of the study may not be directly replicable, the structure of the study could provide a framework for further investigation and the methods chosen and resulting evidence provides some important insights into what very young children might find of value in museums. It thereby reminds us not to lower our expectations of children's capacity for museum literacy: the ability to enter into dialogue with the museum and its objects to create personal meanings from them.

This work adds to and expands upon the ambitions of museum education research more generally, which is to understand how visitors encounter, and make meaning from, museum collections, objects and displays. For example, the high value placed by both adults and children on the unique atmosphere of the museum is also recorded by Luke, Figueiredo and Ong's 2011 study, which drew on 2408 exit interviews and 1513 follow up interviews of art museum visitors. Gradually, the perception (from both within the museum sector and outside it) that traditional museums and galleries are too 'adult' to be of interest to young children is shifting, the findings of this project are part of a growing awareness that young children have richer experiences in these kinds of environments than may have been assumed.

Munley (2012) stresses the importance of museums being able to establish, through robust research evidence, the impact they are having on their young visitors:

In order to demonstrate that traditional museums can contribute to early learning, they must make the case that they are not only places for fun family outings and occasional pre-school field trips, but that they provide the kinds of learning experiences and environments that contribute to the social, cognitive and emotional development of young children (4).

It is vital that this research is carried out by skilled and qualified professionals and that evidence is disseminated appropriately to ensure that claims made stand up to rigorous review. In his report to the Department of Culture, Media and Sport, Anderson (1999) made the case for raising the profile of practitioner-led research in museums, principally among museum staff themselves:

Most museum education specialists (and many other staff) conduct action research as part of their daily work, but it is so closely integrated with other activities such as teaching and the preparation of learning resources that they would not even identify it as research, despite the fact that over a professional career it amounts to a substantial body of new thinking (63).

Definitions are crucial here: if work carried out by museum educators is not thought of as research adding to knowledge within the sector as a whole, it can be reduced to the narrow 
aim of assessing and improving work locally. If it is not disseminated more broadly it will be of limited impact, and will be regarded as having limited credibility outside the institution. External readers may assume that the work is only relevant in the precise context to which it refers. Indeed they may also question the motivation behind it: was it necessary to demonstrate particular outcomes of a project to satisfy funders or other stakeholders? Was evaluation data gathered out of a genuine desire to increase knowledge about visitors and their experiences, or to provide proof that the education department is meeting certain targets or addressing particular policies?

Anderson's suggestion above, that there is a lot of unpublished and hence unknown research carried out by practitioners, may well be true, and unless it is accessible and subject to external rigour, this can only be a source of frustration to those wishing to find out more about museum education, particularly where the youngest children are concerned. Munley (2012), in her review of literature on early learning in museums, explains that,

The literature search revealed that most of the writing about young children in museums take the form of descriptions of programs, tips for working with young audiences and some evaluations of the effectiveness of program designs in attracting and engaging families with young children. Such program profiles and unpublished evaluations are outside of the scope of this review (5)

If Anderson (1999) is correct, then Munley's approach would mean that we are potentially missing out on much information that has been gathered by disregarding this kind of work. Kirk (2011) also identified a gap in the research on very young children in museums, pointing out that much previous work has been carried out by external evaluators or consultants rather than academic researchers. This is perhaps surprising given Anderson's (1999) call nearly twenty years ago for greater integration of research into the work of museum educators. Very young children's museum experiences in particular are still relatively underrepresented in research literature (Munley 2012), policy (DCMS and DfE, 2013) and evaluation (Lord et al., 2012).

It seems a terrible waste if the collective investigations and discoveries of museum educators, who are working directly with young children on a regular basis, cannot be formalized and developed into research that can be shared within and outside the museum community. Carrying out this project has shown me how taking the time to video record and then analyze children's talk and behavior in the museum can reveal the intensity and importance of children's relationships with real objects. Of course, this is something I assume and take for granted on a daily basis: I can sense when children are forging strong connections with the museum objects they see. However, gathering and analyzing data has given me much clearer insight into how and why children are doing this. Additionally, describing these findings to others has helped me to formalize, articulate and justify much that I felt intuitively about young children's museum experiences from my frontline work in this area.

I was able to gain an understanding of the children's experiences precisely because of my role as a practitioner. I am familiar to the children and the adults who were involved in the project, and we have shared experiences together which leads to a feeling of trust. For example, when Emma in this study asked me, 'Where's the picture of the girl called Wendy?', I was able to work out relatively quickly that she was talking about Carpeaux's bronze sculpture La Pêcheuse de Vignots. A researcher, even one with detailed knowledge of all the objects in the museum, without a previous relationship with Emma, could not possibly have made the leap from this description to the object she had in mind.

While many different kinds of research bring new understanding and new perspectives to the field, museum educators run the risk of misrepresenting themselves and their work if they view research as something only carried out by external evaluators or academics, not only because these writers will speak in their own voices, shaped by their own background influences and concerns, but also because they will have different kinds of relationships to those between participants and practitioners. Collaboration and participation in research are important ways of getting young children's voices heard, and thereby improving provision for them (Bowers, 2012).

Although there is still relatively little published research in the area of very young children's understanding of museums, we are not starting from a completely blank slate. 
The nature of this field means that we can draw on findings from education, visitor studies, aesthetic development and early childhood studies among others, not to transplant knowledge or research methods directly from one area to another, but to inform both our practice and our enquiry. Much research is likely to be small scale and locally-focused, particularly when conducted by practitioners themselves, and so in order to be meaningful we must engage with one another and collaborate to share findings and developments within our own practice.

In order to ensure that museums are making a genuinely valuable contribution to the lives of young children and their families, we must identify and make known what (if anything) is unique about this audience, but also what is unique about the museum in contrast to other places frequented by families with young children. How are the needs, interests and potentials of young children best catered for within the diverse museum environments available to them? If we start by considering what it is that young children and their families value when they visit museums then we will understand better what the core of our work should be. Of course, there is much research to be done in terms of addressing issues of access and outreach to non-visiting groups, learning how provision for young children can be developed in harmony rather than in competition with other museum services and evaluating the relative merits of the various pedagogies and teaching approaches which we may use to engage young learners.

In addition, for practitioners to be able to develop rigorous, informative and reliable research, it will be necessary for them to collaborate with academic researchers in order to develop new skills relating to the data gathering and analysis, an awareness of relevant scholarly literature and an understanding of the ethical considerations surrounding research.

Alongside these new skills and partnerships we must keep at the centre of our research the matchless sense of wonder that practitioners working with children in museums see every day. It is this ability to inspire wonder (curiosity, inspiration, ideas, questions) that makes museums so valuable, not just to young children but to people of all ages. Finding value in museum visits from one's earliest years could be the start of a lifelong relationship with museums, their collections and stories.

Received: 14 June 2018

Finally Accepted: 25 October 2018

\section{References}

Allon, H. (1999) 'Working with children and young people' in H. Moffat and V. Woollard (eds) Museum and Gallery Education-A Manual of Good Practice, 77-88, London: The Stationery Office.

Anderson, D. (1999) A Common Wealth: Museums in the Learning Age, Norwich: HMSO.

Anderson, D., Piscitelli, B., Weier, K., Everett, M. and Taylor, C. (2002) 'Children's Museum Experiences: Identifying Powerful Mediators of Learning' Curator 45 (3) 214-229.

Assunçao Folque, M (2010) 'Interviewing Young Children' in G. MacNaughton, S. Rolfe and I. Siraj-Blatchford (eds.) Doing Early Childhood Research: International Perspectives on Theory and Practice, 239-260, Maidenhead: Open University Press.

Bagnall, G. (2007) Museums, Social Capital, and Everyday Life Instrumental Museum and Gallery Policy: issues and opportunities, 3 December, Newcastle University.

Bellamy, K., Oppenheim, C. (eds.) (2009) Learning to Live: Museums, young people and education, London: Institute for Public Policy Research and National Museum Directors Conference.

Black, G. (2005) The Engaging Museum: Developing museums for visitor involvement, London: Routledge. 
Bowers, B. (2012) 'A Look at Early Childhood Programming in Museums,' Journal of Museum Education 37 (1) 39-47.

Bryman, A. (2008) Social Research Methods, Oxford: Oxford University Press.

Clark, A. and Moss, P. (2001) Listening to Young Children: The Mosaic Approach, London: National Children's Bureau.

DCMS and DfE (2013) Cultural Education: A Summary of Programmes and Opportunities, London: DCMS and DfE.

Dowling, M. (2013) Young Children's Thinking, London: Sage.

Edwards, A. (2010) 'Qualitative designs and analysis' in G. MacNaughton, S. Rolfe, and I. Siraj-Blatchford, (eds.) Doing Early Childhood Research: International Perspectives on Theory and Practice, 155-175, Maidenhead: Open University Press.

Graham, J. (2008) 'Close Encounters with Culture: Museums and Galleries as part of the Early Years Foundation Stage',http://www.museum.manchester.ac.uk/medialibrary/ documents/learning/close encounters.pdf,. Accessed 20 September 2013

Graue,M. and Walsh, D. (1998) Children in context: theories, methods, and ethics of studying children, London: Sage.

Gross, J., Hayne, H. and Drury, T. (2009) 'Drawing Facilitates Children's Reports of Factual and Narrative Information: Implications for Educational Contexts', Applied Cognitive Psychology, 23 (.7) 953-971.

Hein, G. (1998) Learning in the Museum, London: Routledge.

Hughes, P. (2010) Paradigms, methods and knowledge in Macnaughton, G., Rolfe, S. and Siraj-Blatchford, I. (eds), Doing Early Childhood Research: International Perspectives on Theory and Practice, 35-61, Maidenhead: Open University Press.

Kirk, E. (2011) Mosaic in the Museum: The Challenge of Adapting the Mosaic Approach to Museum Settings in British Educational Research Association Conference, London, $6^{\text {th }}$ September 2011.

Kirk, E. (2013) 'Gaining Young Children's Perspectives on Natural History Collections' Journal of Natural Science Collections, $138-43$.

Lang, C., Reeve, J. and Woolard, V. (eds.) (2006) The Responsive Museum: Working with Audiences in the Twenty-first Century Aldershot: Ashgate Publishing.

Leinhardt, G. and Crowley, K. (1998) ,Museum Learning As Conversational

Elaboration: A Proposal to Capture, Code,and Analyze Talk in Museums', Learning Research and Development Center, University of Pittsburgh http://mlc.Irdc.pitt.edu/ mlc accessed 13 November 2013.

Lord, P., Sharp, C, Lee, B., Cooper, L., and Grayson, H. (2012) Raising the Standard of Work By, With and For Children and Young People: Research and Consultation to Understand the Principles of Quality, Slough: National Foundation for Educational Research.

Luke, J, Figueiredo, C. and Ong, A. (2011) 'Family Learning in Interactive Galleries: Motivation/Use/Value Study', Institute for Learning Innovation www. familiesinartmuseums.org/pdf/MUV/ExecutiveSummaryFINAL.pdf accessed 2 January 2014. 
MacNaughton, G., Rolfe, S. and Siraj-Blatchford, I. (eds) (2010) Doing Early Childhood Research: International Perspectives on Theory and Practice, Maidenhead: Open University Press.

Moffat, H. and Woollard, V. (eds) (1999) Museum and Gallery Education-A Manual of Good Practice, London: The Stationery Office.

Munley, M. (2012) Early Learning in Museums: A Review of Literature, Smithsonian Institution's Early Learning Collaborative Network and Smithsonian Early Enrichment Centre.

Murray, S. (2009) 'Statistical Report-Renaissance: April 2008-March 2009,'MLA Council http://webarchive.nationalarchives.gov.uk/20110802101741/http://research.mla.gov. uk/evidence/view-publication.php?dm=nrm\&pubid=978 accessed 3 October 2013.

Papatheodorou, T. and Moyles, J. (eds.) (2009) Learning Together in the Early Years: Exploring Relational Pedagogy, London: Routledge.

Pascal, C. And Bertram, T. (2012) 'Praxis, Ethics and Power: Developing Praxeology as a Participatory Paradigm for Early Childhood Research', European Early Childhood Education Research Journal, 20 (4) 477-492.

Piscitelli, B., Everett, M., Weier, K., and the QUT Museums Collaborative (2003) 'Enhancing Young Children's Museum Experiences: A Manual for Museum Staff' www. southbank.qm.qu.gov.au/Learning+Resources/Kids+and+Families accessed 12 September 2013.

Potter, S (2006) Children and Young People in Museum Evaluation (129-131) in Lang, C., Reeve, J. and Woolard, V. (eds.), The Responsive Museum: Working with Audiences in the Twenty-first Century, 129-131, Aldershot: Ashgate Publishing.

Reeve, J. (2006) Prioritising Audience Groups in Lang, C., Reeve, J., and Woollard, V. (eds.), The Responsive Museum: Working with Audiences in the twenty-first century, 43-60, Aldershot: Ashgate.

Rolfe, S. and Emmett, S. (2010) 'Direct Observation' in MacNaughton, G., Rolfe, S. and Siraj-Blatchford, I. (eds.) Doing Early Childhood Research: International Perspectives on Theory and Practice, 309-325, Maidenhead: Open University Press.

Smith, A. (2011) 'Relationships with People, Places and Things - Te Whariki' in Miller, L. and Pound, L. (eds) Theories and Approaches to Learning in the Early Years, (149162)London: Sage.

Taylor, L., (2010) 'Action Research', in MacNaughton, G., Rolfe, S. and Siraj-Blatchford, I. (eds), Doing Early Childhood Research: International Perspectives on Theory and Practice, 291-307, Maidenhead: Open University Press.

Wavell, C., Baxter, G., Johnson I. and Williams, D. (2002) 'Impact Evaluation of Museums, Archives and libraries: Available Evidence Project', The Council for Museums, Libraries and Archives http://www4.rgu.ac.uk/files/imreport.pdf accessed 18 October 2013.

Weier, K. (2004) ,Empowering Young Children in Art Museums: letting them take the lead' in Contemporary Issues in Early Years, 5 (1) 106-115.

Wilkinson, S. (1999) 'Developing a Policy for an Education Service' in Moffat, H. and Woollard, V. (eds) Museum and Gallery Education-A Manual of Good Practice, 1122, London: The Stationery Office. 
Wu, K. (2011) 'What do families with children need from a museum?' http:// culturalpolicyjournal.files.wordpress.com/2011/05/ejournal2 wu.pdf accessed 31 March 2013.

Xanthoudaki, M., Tickle, L. and Sekules, V. (eds.) (2003) Researching Visual Arts Education in Museums and Galleries: An International Reader, Dordrecht: Kluwer Academic Publishers.

Nicola Wallis: Museum Educator, The Fitzwilliam Museum

Following undergraduate studies in Modern and Medieval Languages at Cambridge University, Nicola trained as a primary school teacher, and then read for a post-graduate diploma in Museum Studies. She has specialised in Early Years Education since 2005, and has an MA in Early Childhood Studies. She began working in Museum Education in 2007.

Research Interests: Early childhood education; young children in museums; arts \& cultural education in the Early Years; practitioner-led research; child-centred practice; participatory research methods; the role of Early Years Education in promoting democratic engagement and social justice.

nlw30@cam.ac.uk 